\title{
Institutional change and routine dynamics in service ecosystems
}

\author{
Tiina Tuominen \\ Faculty of Management and Business, Tampere University, Tampere, Finland \\ Bo Edvardsson \\ Service Research Center-CTF, Karlstad University, Karlstad, Sweden, and \\ favier Reynoso \\ EGADE Business School, Tecnologico de Monterrey, Mexico
}

\begin{abstract}
Purpose - This study aims to understand and explain how institutional change occurs at the level of value co-creation practices in service ecosystems. Despite the centrality of collective practices to the service ecosystems perspective, theoretically grounded explanations of how practices change and become institutionalized remain underdeveloped. Applying the theory of routine dynamics, this paper addresses two questions as follows: what does the institutional change mean at the level of value co-creation practices and what processes underlie these changes?

Design/methodology/approach - The study develops a conceptual framework that characterizes value co-creation practices as routines involving three aspects, namely, ostensive, performative and artifactual. As a key element in institutional change, the interplay between these informs an account of institutional change processes in service ecosystems.

Findings - The proposed conceptual framework specifies the conditions for institutional change in terms of value co-creation routines. First, any such change is seen to be grounded in alignment between changing institutional rules and the ostensive, performative and artifactual aspects of routines. Second, this alignment is seen to emerge through a dialectics of planned and practice-based activities during institutional change. An empirical research agenda is proposed for the analysis of institutional change processes in different service ecosystems.

Originality/value - This conceptual framework extends existing accounts of how service ecosystems change through the contributions of multiple actors at the level of value co-creation practices.
\end{abstract}

Keywords Co-creation, Service ecosystem, Service processes, Service dominant logic SDL, Value co-creation practices, Routine dynamics, Institutional change, Actors, Dialectics, Coordination, Agency

Paper type Conceptual paper

\section{Introduction}

When multiple actors come together to create value, concerted action and interaction depend crucially on collective practices ways of understanding, saying and doing things together (Schau et al., 2009). Service-dominant logic (SDL) is one of the several approaches that highlight the importance of practices that enable multiple actors to co-create value by integrating resources (Vargo et al., 2015). For example, when children begin school, teaching and learning practices in the school ecosystem enable the children, teachers and parents to quickly understand what is expected of them and how they should interact to ensure beneficial outcomes for all. Although the actors change, these practices persist with each new intake of pupils. By analyzing value co-creation practices among different actors in their social and institutional context, the service ecosystem perspective provides a useful theoretical lens for understanding such systems. To date, however, no

The current issue and full text archive of this journal is available on Emerald Insight at: https://www.emerald.com/insight/0887-6045.htm

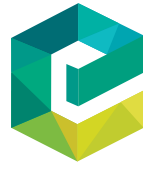

Journal of Services Marketing

34/4 (2020) 575-586

Emerald Publishing Limited [ISSN 0887-6045]

[DOI 10.1108/JSM-06-2019-0243] conceptual framework has adequately captured how value cocreation practices change in service ecosystems.

Drawing on institutional theory, many SDL studies associate innovation and change in service ecosystems with processes of institutional change, in which taken-for-granted rules are altered and resources and practices are recombined to develop novel solutions to new or existing problems (Vargo et al., 2015; Koskela-Huotari et al., 2016). These studies confirm that change processes of this kind involve various actors and activities and evolve in unforeseen ways (Meynhardt et al., 2016; Mele et al., 2018; Banoun et al., 2016). However, they do not explain in detail how value co-creation practices in service

(C) Tiina Tuominen, Bo Edvardsson and Javier Reynoso. Published by Emerald Publishing Limited. This article is published under the Creative Commons Attribution (CC BY 4.0) licence. Anyone may reproduce, distribute, translate and create derivative works of this article (for both commercial and non-commercial purposes), subject to full attribution to the original publication and authors. The full terms of this licence may be seen at http://creativecommons.org/licences/by/4.0/legalcode

Dr Tuominen received funding from the Finnish Work Environment Fund and the Evald and Hilda Nissi Foundation in the initial stages of the research process.

Received 24 June 2019

Revised 26 September 2019

9 January 2020

Accepted 18 January 2020 
ecosystems concurrently change without creating adverse effects or disintegrating during multiple and sometimes contradictory change initiatives (Banoun et al., 2016; Lusch and Nambisan, 2015). Returning to the school example, new ideas such as experiential and self-directed learning have transformed school ecosystems in countries such as Finland. Classroom walls are torn down, classes are mixed and teachers become facilitators while students take more responsibility for their own learning processes. Beyond those who plan such curriculum reforms, teachers influence their implementation by interpreting them in the local context. In turn, parents and students may find the changes advantageous or confusing, depending on their resources (Pietarinen et al., 2017). For that reason, it is difficult to anticipate the form these revised practices will take and how they might affect different actors. In short, altering shared institutional rules can lead to problems, ambiguities and opportunism, so diminishing the potential for value co-creation (Mele et al., 2018; Meynhardt et al., 2016). Clearly, then, there is a need for a better theory of how value cocreation in service ecosystems can remain coordinated when institutions change.

To conceptualize change in value co-creation practices, the present study applies the theory of routine dynamics (Feldman and Pentland, 2003), which is a variant of practice theory (Feldman and Orlikowski, 2011). Value co-creation practices are analyzed as collective routines: they are dynamic and evolving systems, comprising three interdependent aspects, namely, ostensive (shared schemas), performative (everyday value co-creation encounters) and artifactual (formal resources) (Feldman, 2000; Feldman and Pentland, 2003). While the value co-creation literature has addressed similar aspects (Edvardsson et al., 2011; Edvardsson and Tronvoll, 2013; Echeverri and Skålén, 2011), routine dynamics theory helps to explicate change by analyzing the interplay between these three aspects during the process of change.

This paper argues that a routine-based view offers a means of explaining the viability and sustainability of change in service ecosystems. A theoretical framework is developed in this paper to maintain that institutional change in value co-creation routines requires alignment between the institutions and the ostensive, performative and artifactual aspects of routines. Next, as different change activities may influence routines in contradictory ways, the framework directs attention to the dialectics of change activities in institutional change processes. Such a dialectical view helps to explain how value co-creation practices change through the contributions of multiple actors in service ecosystems.

After reviewing recent studies of institutional change in service ecosystems, the paper goes on to discuss the theory of routine dynamics and its application to the study of institutional change at the level of value co-creation practices. This forms the basis for future research agenda exploring institutional change processes empirically in different types of service ecosystems. The paper concludes with a discussion of key contributions and limitations of the proposed conceptual framework.

\section{Institutional change in service ecosystems}

Responding to the general call for a multi-actor account of value creation and service innovation (Windrum et al., 2016; Hollebeek et al., 2018; Carlborg et al., 2014), SDL has broadened the firm-centric view to encompass wider actor networks and systems in the marketplace. To that end, SDL introduced the concept of the service ecosystem, which can be defined as a system of social and economic actors that cocreates value by exchanging services (Lusch and Vargo, 2014; Lusch and Nambisan, 2015; Vargo and Lusch, 2016). In this view, individual actors (such as firms) have limited control over value co-creation and change in service ecosystems. Instead, these are viewed as self-organizing systems (Meynhardt et al., 2016) or emergent entities that evolve through interactions between actors with different resources and intentions (Lusch and Nambisan, 2015). According to Lusch and Nambisan (2015, p. 161),

Effectual actors decide what they can do in the constrained and unpredictable world they experience and in so doing they shape their context; other actors do the same and thus they collectively create their environment or the service ecosystem. Service ecosystems are thus emergent A2A structures.

To understand what guides and coordinates interactions among multiple actors in service ecosystems, researchers have turned to sociological theories, assigning a key role to institutions. Defined as resilient social structures (Scott, 2001) with enduring rules, norms, schemas and beliefs (Vargo et al., 2015), SDL researchers contend that assemblages of institutions condition service ecosystems (Vargo and Lusch, 2016; Koskela-Huotari et al., 2016). For example, interactions in financial ecosystems are coordinated by financial, legal and cultural institutions that both enable and constrain actors' interactions and determine their resources. Equally, value cocreation interactions can drive institutional change (Vargo et al., 2015). As institutions play an important role in value cocreation, institutional change (Koskela-Huotari et al., 2016; Vargo et al., 2015) in service ecosystems results in new rules, resources and practices that diffuse and become legitimized over time (Lawrence et al., 2001; Lusch and Nambisan, 2015; Koskela-Huotari et al., 2016).

Earlier studies have characterized institutional change processes as complex and evolutionary, involving multiple actors and sub-processes (Vargo et al., 2015; Banoun et al., 2016). When actors with different intentions and resources interact, these processes are likely to take unanticipated turns (Banoun et al., 2016; Lusch and Nambisan, 2015) and although a firm may introduce new value propositions, changes become institutionalized only after a significant journey. For example, Banoun et al. (2016, p. 2990) noted that following the introduction of a service platform, ecosystems "evolve and alternate between phases of tensions and phases of solutions where each new agreement between the actors of the service ecosystem becomes increasingly stable".

Because of ambiguities in the process, opportunistic behavior, power plays or mismatches between resources and practices, institutional change does not automatically result in beneficial outcomes (Chowdhury et al., 2016; Nenonen et al., 2018; Mele et al., 2018). The service ecosystem perspective, therefore, invites questions about how tensions and conflicts affect the coordination of multiple actors. One key question concerns how a service ecosystem can change without disrupting coordinated value co-creation actions and interactions. Some researchers have argued for the importance of maintaining certain rules (Koskela-Huotari et al., 2016) and 
shared intentionality (Taillard et al., 2016) when institutional rules are changed or broken, but these studies do not specify how value co-creation practices actually change. To fully understand institutional change, the present paper contends that changing value co-creation practices must be explored in greater detail. Although sometimes discussed as the target of change and as a medium through which changes may happen (Vargo et al., 2015; Chandler and Chen, 2016), these practices are often treated as a black box in studies of institutional change in service ecosystems, with no analysis of their internal dynamics. This paper argues that a practice-based view of routine dynamics (Feldman and Pentland, 2003) can address this shortcoming. The next section provides an overview of this theory and suggests how it can illuminate the nature of change at the level of value co-creation practices.

\section{The theory of routine dynamics}

As one variant of practice theory, the theory of routine dynamics treats routines as generative systems that produce "repetitive, recognizable patterns of interdependent actions, carried out by multiple actors" (Feldman and Pentland, 2003, p. 95; Feldman et al., 2016). It partially overlaps with earlier accounts of practices in service research. For example, service researchers have applied Schau et al.'s (2009) conceptualization of practices as procedures, understandings and engagements (Echeverri and Skålén, 2011) and Shove et al.'s (2012) characterization of practices as competences, materials and meanings (Genus and Jensen, 2019). While similarities exist, the theory of routine dynamics is especially useful in exploring how practices change in service ecosystems, as it explicitly addresses the internal dynamics of practices (i.e. relations between the ostensive, performative and artifactual aspects) in change processes. For present purposes, then, value co-creation practices are understood as collective routines. Before turning to the proposed theoretical framework, the next section summarizes the key arguments of the theory of routine dynamics.

\section{Interrelated aspects of routines}

Drawing on Giddens (1984), early versions of routine dynamics theory suggested that routines involve two mutually constitutive aspects, namely, ostensive and performative (Feldman and Pentland, 2003; Howard-Grenville, 2005). Ostensive aspects include partially shared understandings and informal rules and norms, which are referred to here as schemas (Dionysiou and Tsoukas, 2013). In consulting routines, for example, ostensive aspects might include schemas for how consultants can help their clients, what skills they need and how clients and consultants should interact for their mutual benefit. These schemas are relatively durable; in contrast, performative aspects refer to situated routine performances. As non-habitual actions, these may be varied and improvisational, as they depend on the resources and intentions of the actors involved and on the similarity of their schemas (Feldman and Pentland, 2003). It follows that even stable routines may vary significantly in terms of performance (Pentland et al., 2011); for example, consulting routines prescribe various ways of interacting and solving problems, depending on the nature of the problem and the skills and intentions of consultant and client. These performances may strengthen or alter shared schemas.

More recent studies include artifacts as the third aspect of routines (D'Adderio, 2011). Artifacts include formal material and immaterial resources used in routine performances (Cacciatori, 2012; Pentland and Feldman, 2008). It is similar to the concept of service prerequisites (Edvardsson and Olsson, 1996) or service designs (for example, Wetter-Edman et al., 2014). In service ecosystems, artifacts may include service models, platforms, blueprints, self-service technologies, web-based tools and formal rules. While a firm may design these formal resources prior to value co-creation performances, individual actors can also interpret and use them in unintended and creative ways (Orlikowski, 2000; Pentland and Feldman, 2008).

The theory of routine dynamics suggests that the continuous interplay between the above three aspects explains both stability and change in routines (Feldman, 2000). Figure 1 illustrates the proposed conceptualization of these dynamics in value co-creation routines. When different actors share similar schemas, and when artifacts align with these schemas, similar performances can be repeated across space and time, so explaining why routines remain the same (Feldman, 2000; D'Adderio, 2011). As discussed below, change in routines involves changes in all three aspects but can begin from any of them.

\section{Two forms of routine change: practice-based and planned}

Studies of routine dynamics commonly refer to two types of change, namely, internal or "practice-based" and external or planned (Feldman et al., 2016). Internal practice-based change begins from performance when individual actors introduce new resources and perform routines differently (Giddens, 1984; Feldman and Pentland, 2003; Pentland and Feldman, 2008). While improvisations may frequently occur, not every new performance leads to a change in routine. Change requires the establishment of new ostensive understandings; new performances are repeated and artifacts are modified. This type of change happens when useful new performances are copied and repeated by multiple actors, renewing other aspects of the routine (Feldman and Pentland, 2003). For example, Orlikowski (1996) described how organizational actors in a

\section{Figure 1 Routine dynamics}

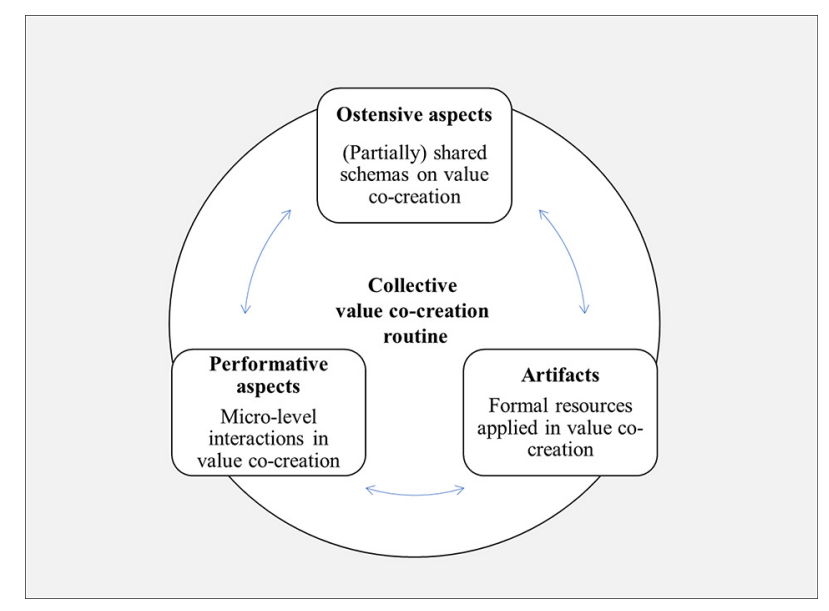


software company transformed customer support practices gradually but profoundly through improvisation and experimentation when using a new call-tracking system.

External planned change refers to broader intentional change projects initiated beyond the routine itself by stepping out of the everyday performance to assess and redesign the routine (Feldman et al., 2016; Bucher and Langley, 2016; Dittrich et al., 2016). These change processes often involve the creation of new artifacts (e.g. guidelines, process models and tools) that play a key role in supporting change (Pentland and Feldman, 2008). In service contexts, planned routine change often forms part of new service development (Yu and Sangiorgi, 2018). While planned change projects are an important means of assessing and revising a routine (Deken et al., 2016; Bucher and Langley, 2016), micro-level empirical studies have shown that changes rarely happen as planned. In particular, planned changes may fail if routine participants are required to follow new routines that do not correspond to their needs, resources or interests (D'Adderio, 2008; Pentland and Feldman, 2008). In these circumstances, they may change or abandon the new design, decoupling actual and planned routines (Sandholtz, 2012).

Recent studies have suggested that these two types of change are only starting points or phases in the continuous evolution of routines. Iteration is inevitable because any change can have unanticipated consequences for different aspects and outcomes of a routine (Feldman, 2004). In general, routines can be said to evolve through continuous interactions among the three aspects (Feldman and Pentland, 2003), as well as between planned and practice-based change activities (D'Adderio, 2008; Bucher and Langley, 2016; Pentland et al., 2012) andin complex contexts such as service ecosystems - between interrelated routines (Kremser and Schreyögg, 2016). In this view, the focus of research shifts from individual change episodes or projects to continuous change, which aligns well with accounts of institutional change in service ecosystems.

\section{An extended conceptualization of institutional change grounded in the theory of routine dynamics}

The theory of routine dynamics is next applied to institutional change at the level of value co-creation practices in service ecosystems. Value co-creation practices are conceptualized as interrelated routines to address two questions as follows: what does the institutional change mean at the level of these routines and what are the institutional change processes that lead to these outcomes?

\section{Institutional change incorporated in routines}

Previous studies have suggested that routines are the carriers of institutions and that institutional change must be routinized to become viable and sustainable in practice (Scott, 2001; Lawrence and Suddaby, 2006). However, the question of what this actually means in the context of service ecosystems has not been adequately conceptualized. This paper contends that institutional change depends on alignment between institutions and the three aspects of routines to ensure that actors know what is expected in value co-creation performances. This alignment can be analyzed at two levels, namely, within routines and between institutions and routines.

As schemas or (informal) rules and norms are seen as central elements of both institutions and routines (Feldman and Pentland, 2003; Vargo et al., 2015), it is proposed here that the alignment of schemas associated in institutions and routines serves as an index of overall alignment between these two levels. These schemas are unlikely to be identical even if they are aligned; while institutions typically guide actions at a more general level, the ostensive aspects of a routine comprise schemas that are specific to that particular routine. For example, air travel as an institution defines general norms that guide the relationships between crew members and passengers; in contrast, interactions in particular situations are guided by an ostensive understanding of detailed security and quality assurance routines monitored by the International Air Transport Association. Additionally, the ostensive aspects of value co-creation routines are likely to combine schemas from several institutions. For example, consultancy routines may incorporate schemas and norms from industrial and national cultures and from the ethics of professional service practice. Together, these schemas influence consultants' sense of whether and how they might, for example, challenge a client's strategy. This paper contends that ostensive aspects of routines concretize and mediate the influence of institutions on value co-creation performance (Figure 2) and that alignment means that the ostensive aspects of routines accommodate relevant schemas from the related institutions. In these circumstances, actors understand how to perform a routine while taking account of the diverse norms and expectations of the social context.

It is further argued here that institutional change requires internal alignment of value co-creation routines - that is, all three aspects of routines must be aligned to enable the concerted performance of novel routines by multiple actors. While the multiplicity of actors and the evolving nature of service ecosystems make complete and stable alignment unlikely, actors' schemas must be sufficiently similar (Echeverri and Skålén, 2011; Dionysiou and Tsoukas, 2013), and artifacts should support them. Without this common base for interaction, actors may deviate from routines in ways that

Figure 2 Two types of change activities and their influence on routines

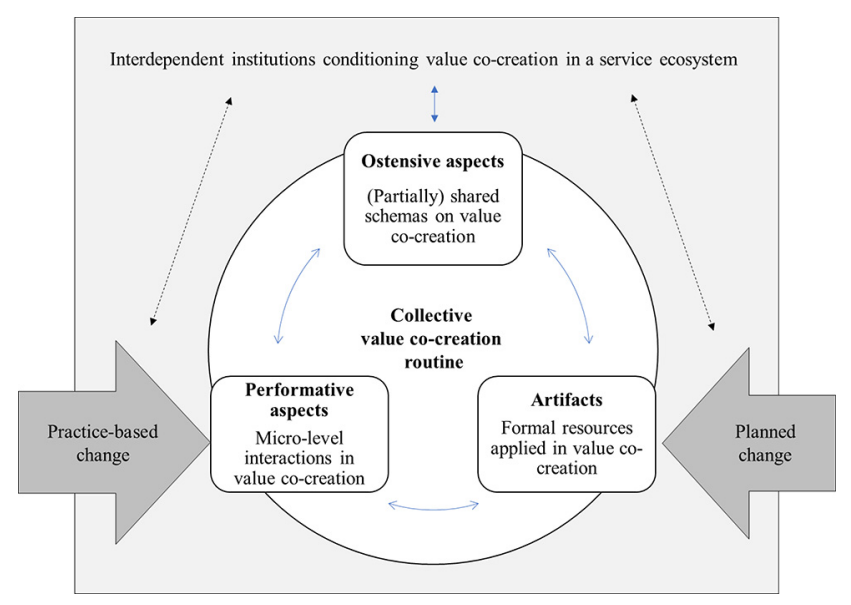


challenge value co-creation (Echeverri and Skålén, 2011; Pentland and Feldman, 2008).

In this view, changes in service ecosystems are unlikely to become sustainable and institutionalized unless all three aspects of routines change interdependently. For example, a new way of co-creating value involving two actors will not lead to institutional change unless other actors consider it useful and change their schemas and performances accordingly; otherwise, it remains merely an ad hoc variation in routine performance. In the consultancy business, for example, the numerous customer-specific variations rarely lead to broader change (Gallouj and Weinstein, 1997; Toivonen and Tuominen, 2009; Witell et al., 2016). Furthermore, for institutional change, the introduction of a new service platform or technology must be accompanied by changes in actors' schemas and routine performances; otherwise, it is just a new artifact (Pentland and Feldman, 2008; see also Vargo et al., 2015). As proponents of SDL have argued (Vargo et al., 2015), the institutional change should result in novel value co-creation performances across multiple contexts.

A number of service studies have demonstrated the nature of such a profound change. For example, Banoun et al. (2016) analyzed how the relationships between service providers and internal customers in large firms evolved through several phases from goods-dominant to SDL following the introduction of shared support service centers. The above framework explains these change processes at the practice level when the analyst explores how routines evolved from "old" to "new" alignment. Banoun et al. (2016) showed that service centers initially adopted a goods-dominant, industrial worldview that probably guided their ostensive understanding of routines. This view was supported by standardized procedures (artifacts) that suggested dyadic formal interactions among employees and clients (routine performances). However, differences of worldview among employees and clients led to tensions through which the ecosystem evolved, finally (temporarily), reaching an institutionalized form that can be said to include interdependent changes in the three aspects of routines. The actors shared a collaborative worldview (implicated in new ostensive aspects), supported by new technological platforms (new artifacts) that encouraged collaborative value co-creation performances among wider networks of actors (new types of performance).

In particular, this case shows that new ostensive understandings and artifacts did not realize institutionalized routines until all actors agreed on their relevance for value cocreation. During the process, adjustments and compromises were required until the different aspects aligned across the service ecosystem.

\section{Institutional change as dialectical process}

Given the multiplicity of actors and routines embedded in service ecosystems, institutional change processes can be characterized as extended (or continuous) political processes (Lusch and Nambisan, 2015; Vargo et al., 2015) that may not automatically generate fair or beneficial outcomes for all actors (Mele et al., 2018). While service ecosystems are guided by shared institutions, actors are likely to differ in terms of position and institutional background. Consequently, they may introduce their own schemas and resources to change the routine or to prevent change (Lawrence et al., 2011; also Mele et al., 2018). Here, the theory of routine dynamics is applied to determine which processes might lead to sustained beneficial changes in value co-creation routines.

From the perspective of routines, it is important to acknowledge that institutional change processes are likely to include both planned and practice-based activities as different actors react to each other's initiatives. Figure 2 summarizes the present conceptualization of how these change activities influence routines; while planned change activities often culminate in the introduction of new artifacts, practice-based changes are embodied in routine performances (Pentland and Feldman, 2008). These activities are not necessarily mutually supportive but may instead reflect tensions and conflicts among actors and activities. New artifacts do not necessarily serve different use situations - numerous studies have shown that information technology systems are not adopted as planned (Pentland and Feldman, 2008). Unintended variations might occur if old routines are altered and new versions are not accepted. These variations not only may be useful but also conflict with the designers' intent, so highlighting a need for further change (Pentland and Feldman, 2008; Feldman, 2004).

The paper contends that the interplay of these different change activities determines whether and how the institutional change will occur at the level of routine. Service studies have tended to distinguish planned and practice-based activities as differences of perspective or process (Skålén et al., 2015b) rather than as activities within the ongoing process of institutionalization. To assess their joint effect on routine, this paper instead views institutional change as a dialectical process, in which cycles of planned and practice-based change activities oppose or build on one another as shown in Figure 3.

In dialectical change processes, different activities or actors build on or contradict each other and compromise solutions emerge when these contradictions are resolved (Van de Ven and Poole, 1995). The dialectical conceptualization proposed here directs attention to how different change activities respond to each other's outcomes and how they can provide mutual support in aligning routines (Bucher and Langley, 2016). While recent service studies adopting a dialectical view have focused on the tensions between different actors (Taillard et al., 2016; Nardelli, 2017), a shift of focus to change activities acknowledges that the same actors may be involved in multiple activities but with different roles, power relations and interests in each case. How these actors behave in different cases provides valuable information about the institutionalization process.

As discussed above, Banoun et al.'s (2016) study of shared service centers illustrates these dialectical processes and the different roles that actors play. At first, the service centers deferred to their industrial worldview, planning rigid formal procedures (artifacts) without engaging with customers during the design process. Dissatisfaction and clashes of worldview between clients and employees led to practice-based changes involving temporary local arrangements to support value cocreation. Subsequently, the service centers involved their clients in the planning process to develop compromise solutions (Banoun et al., 2016). Throughout the process, tensions between employees (who were in charge of planning processes) and clients (who reacted to the plans through value 
Figure 3 Dialectical model of the institutional change process

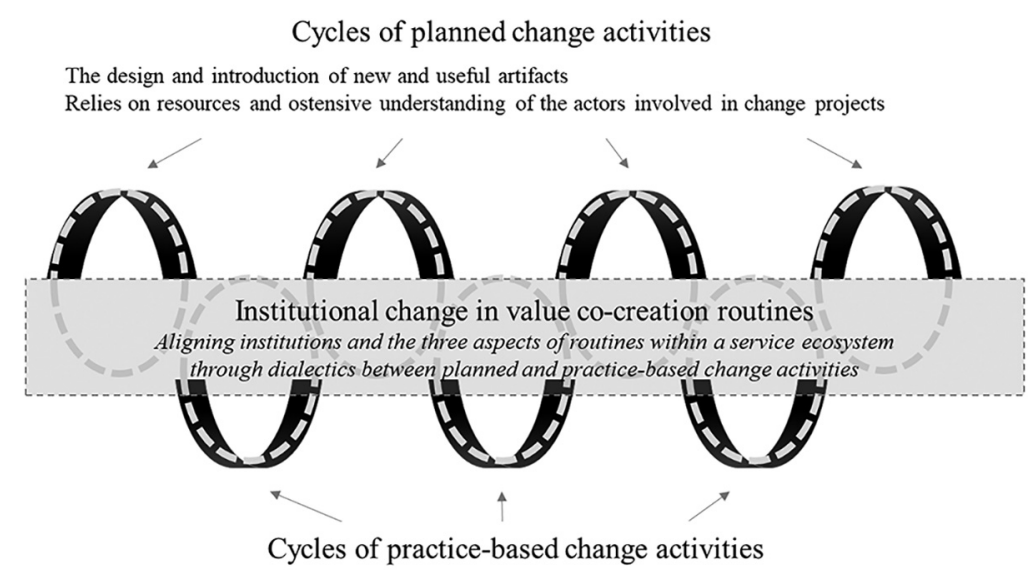

Comprises new performances where artifacts are applied in situated manner Relies on resources and ostensive understanding of practitioners in their daily micro-level interactions

Time

co-creation performances) prompted changes in the evolving service ecosystems.

\section{Coordinating the dialectics of institutional change}

The proposed framework affords novel insights into how actors can facilitate institutional change. Previous studies have suggested that open dialogue and non-predictive strategies can help central actors to shape service ecosystems (Mele et al., 2018); the present dialectical account extends this view by redirecting attention from single product/service development projects to the coordination of the various activities that contribute to institutional change. Because these activities exert different influences on the three aspects of routines, actors can facilitate institutional change by identifying tensions and opportunities between planned and practice-based activities in pursuit of the best possible compromise.

Some studies of routine change have suggested that planned change activities should be seen as processes of collective sensemaking and selection (Pentland et al., 2012), integrating learnings from practice-based changes across routines. In service ecosystems, it might be possible to justify such a role for planned change activities to institutionalize change. While it is unlikely to be possible to control practice-based changes across service ecosystems, the best novel performances can be collected, reflected on and shared using appropriate artifacts during planned change activities (Pentland et al., 2012; also Kimbell, 2011). This approach requires dialectics and responsiveness between change projects and on-going routine performances.

The importance of coordinating dialectics during the institutional change process can be illustrated by the case of a self-sustainable housing solution called Patrimonio Hoy, created for the Mexican low-income market segment by CEMEX, a global cement manufacturer (London, 2012; Segel et al., 2006). The solution emerged through a cyclical process, during which CEMEX changed its offering entirely from a bag of cement (1998) to a housing solution (2001). After launching the original cement product, CEMEX had to review why lowincome communities had difficulty incorporating the product in their construction routines. This led to several cycles of planned changes and practice-based learning as CEMEX and its networks sought to integrate their expertise with the schemas and resources embedded in this new market. Their final revised solution provided communities with building materials, technical assistance and logistical support, as well as a microfinance system, which mimicked elements from informal group routines within the target communities (London, 2012; Segel et al., 2006). This case demonstrates the importance of building on variations and tensions in routine performance rather than defending the originally planned routines, so achieving alignment between the new routines and the surrounding institutions. In 2004, CEMEX's housing concept became self-sustaining, creating a new business line that subsequently expanded into Latin America, benefiting more than two million people.

In summary, the proposed dialectical conceptualization of institutional change at the level of routines builds on the earlier view that service ecosystems emerge through the contributions of multiple actors (Lusch and Nambisan, 2015; Edvardsson and Tronvoll, 2013) and extends this account by explaining how different activities influence value co-creation routines in the process of institutional change. It also explains how challenges arise when different change efforts influence the ostensive, performative and artifactual aspects of routines in conflicting ways, resulting in unanticipated outcomes. In highlighting the conditions likely to support the institutionalization of change, this framework has normative implications for future research. First, it suggests that institutions and the three aspects of routines should be aligned, even if temporarily and incompletely. Second, it conceives of institutionalization as a dialectical process and assumes that coordination - that is, facilitating the dialectics between change activities - is often necessary to institutionalize novel and useful changes in routines and improve the possibilities for value cocreation in service ecosystems. The next section considers what this means for future empirical studies. 


\section{Suggestions for future research}

This paper argues that further empirical research on the dialectics, coordination and alignment in institutional change processes will help service researchers to understand and explain institutional change at the level of value co-creation routines. In particular, the question of when and how different actors initiate and contribute to institutional change processes in different contexts and situations must be explored in depth. Adopting this actor-centric view will help to specify the circumstances in which planned and practice-based activities emerge and how they influence institutional change in value cocreation routines in different service ecosystems.

Two research streams are proposed. The first of these analyzes actors' capacity to influence other actors - in other words, the internal power dynamics of institutional change. The second stream zooms in on the context of action - that is, how the processes of institutional change differ across service ecosystems, which vary in terms of the institutional environment and the complexity and materiality of routines. Together, these lines of inquiry can explain how value cocreation routines evolve during institutional change.

\section{Power dynamics in dialectical change}

Many studies note that power dynamics influence how a change process begins and evolves (Chowdhury et al., 2016; Nardelli, 2017; Taillard et al., 2016; Van de Ven and Poole, 1995). Here, power dynamics refers to how different actors exercise their agency to influence one another and so contribute to routine change in planned and practice-based change activities (Giddens, 1984; Howard-Grenville, 2005). By analyzing these dynamics, researchers and practitioners can anticipate the consequences of change activities and their dialectics in different situations, and how best to facilitate these dialectics. Three research questions are identified and discussed below.

RQ1.1. How can different actors initiate change in value cocreation routines?

This question invites researchers to map the various ways in which actors initiate change in service ecosystem value cocreation routines. The above discussion suggests that change can begin either from novel routine performances or from planned service development activities and that each starting point brings its own challenges. Where changes arise from routine performance, the challenge is to scale up the new performance. Improvising actors do not necessarily recognize changes in their ostensive understanding (Tsoukas and Chia, 2002) and they may alter their own performances without intending to change the entire system; others may need to replicate these performances to change the broader ecosystem (Di Pietro et al., 2017). On the other hand, where change begins from the planning of new routines, the challenge is to adjust these routines for different contexts to fit the schemas and resources of actors across the service ecosystem.

Recognizing these alternative starting points helps to clarify the complexities of coordinating any change process. It seems likely that several change initiatives of different types will occur simultaneously within a service ecosystem and these must be coordinated to deliver a collective outcome on routines. Further empirical research is needed to understand how the coordination of multiple collaborating actors is achieved in different situations.

RQ1.2. How do individual actors influence routines in the cycles of planned and practice-based change activities?

This question delves deeper into the issue of how differently positioned actors exercise agency in planned and practicebased change activities (Feldman and Pentland, 2003; Howard-Grenville, 2005), and under what circumstances their actions might alter the direction of change. For example, users typically propose novel ideas in service development projects but have limited decision-making power. In practice-based change, they exercise their agency by deciding whether and how to engage in given routines (Feldman and Pentland, 2003). Conversely, service providers make decisions regarding service designs but have limited influence on routine performances. These dynamics may differ across service ecosystems; for example, user-driven changes play a key role in many technology-enabled service ecosystems such as Apple, which has a closed operative system but has been very successful in promoting app-related user-driven innovation. Because apps are important to Apple, users exert significant influence on the ecosystem's design and development.

Actors may also enjoy unexpected agency grounded in their various roles and resources such as social networks and skills (Akaka and Chandler, 2011; Baker and Nelson, 2005). Coordination efforts may fail if these sources of the agency are not taken into account, as actors may develop local versions of routines rather than contributing to collective routines. In other cases, entire service ecosystems can be transformed without any formal power. In their study of the Arab Spring uprising, Skålén et al. (2015a) showed how activists were able to transform four interdependent service systems - media, social movement, healthcare and financial - by integrating resources and cocreating value using a range of technologies. Further research is needed to understand the nature of agency in institutionalization processes in different situations and contexts.

RQ1.3. How do changing power relations among different actors influence the dialectics in an institutional change process?

This question asks how and why power relations change during an institutionalization process, so influencing the evolution of routines and the need for flexibility in coordination, as changing resources and positions may increase or reduce agency (Levina and Orlikowski, 2009; Feldman, 2004). Roy and Harigan's (2008) study of India's Barefoot College illustrates how changes in power relations can influence the dialectics of planned and practice-based change in unanticipated ways. Barefoot College educates illiterate rural women about the use of solar panels to bring electricity to remote villages. By creating new routines and roles, Barefoot enabled the rural poor to integrate their previously underappreciated resources to create value. These changes empowered the poor and increased their self-sufficiency, prompting several power struggles during the change process as a result of resistance from actors who had traditionally dominated. Dependence on urban professionals' expertize was 
intentionally reduced, enabling the rural poor to overcome poverty unaided. As they gained more power, other actors became less important (Roy and Harigan, 2008). Further empirical research is needed to investigate how and when power relations change, how this change influences the evolution of routines, as well as how actors resist such changes in power relations and whether this resistance can stifle institutional change.

\section{Change processes in service ecosystems of different kinds}

The proposed second stream of future empirical research would explore how the characteristics of service ecosystems influence the prioritization and coordination of planned and practice-based change activities during institutional change. This responses to the call to investigate ecosystem differences across regions and countries with different institutional and cultural contexts (Ostrom et al., 2015). The framework proposed here addresses this issue by specifying three factors that are likely to influence institutional change in value cocreation routines, namely, institutional diversity, the complexity of value co-creation routines and routine formality and materiality.

RQ2.1. How does the diversity of service ecosystems' surrounding institutions influence the dialectics of the institutional change process?

Institutional diversity is likely to shape the power dynamics and dialectics of change in different ways. Where service ecosystem actors are embedded in different institutional contexts, resource differences and the cognitive distance between them will be greater (Lusch and Nambisan, 2015). Although this diversity can provide inputs for innovative change (Siltaloppi et al., 2016), the development of shared routines is likely to be difficult, as actors' ostensive understandings must be unified. For example, there are usually extensive institutional differences between users and firms in services targeting lowincome market segments commonly referred to as base of the pyramid. As demonstrated earlier by the CEMEX case, these differences may result in multiple iterations of routine performance and redesign, confirming the need for constant adaptation to varying conditions.

When actors share the same institutional context, change processes are likely to entail less learning and fewer conflicts, as in the case of Dabbawala, a service cooperative delivering food boxes in Mumbai. Because its 5,000 cooperative members are deeply embedded in the local culture and institutions, they can shape the complex routine dynamics of their logistics network without significant conflict. This kind of service ecosystem is impossible to replicate, as it is based on intrinsic knowledge of actors, schemas, resources and artifacts such as railways, villages, streets and families (Thomke, 2012). Future research should assess the influence of different institutional contexts on the institutionalization of new value co-creation routines.

RQ2.2. How does the complexity of routines within a service ecosystem influence the dialectics of institutional change process?
The complexity of service ecosystem routines is also likely to influence the dialectics of change activities. For present purposes, complexity is defined in terms of the number of routines and their interdependencies within a service ecosystem. As every service ecosystem includes multiple value co-creation routines (managerial, sales, frontline, user-to-user, etc.), different subgroups have different routines and partly different ostensive understandings. For example, international payments using SWIFT, the global interbank system, depend on multiple systems and routines, guided by multiple laws and regulations (Ambrosia, 1981). In contrast, the ecosystem around the transportation network company Uber Technologies is based on simple and effective routines supported by mobile apps, with drivers and users around the world following the same routines (Cramer and Krueger, 2016).

Complexity is likely to increase iterations of the planned and practice-based change activities required to ensure alignment within and among routines. Complex dependencies between routines mean that change in one routine influences others and innovators must take account of coordination and adaptation issues (Kremser and Schreyögg, 2016). To understand these dynamics, further empirical research should compare institutionalization processes in more and less complex ecosystems.

RQ2.3. How do service ecosystem formality and materiality influence the dialectics of institutional change process?

Furthermore, the formality and materiality of value co-creation routines are likely to influence the dialectics of institutional change processes. Some service ecosystems depend extensively on formal and/or material artifacts such as physical spaces, tools or information and communication technology (ICT). For example, financial service ecosystems rely on standardized ICT systems to ensure consistent standards of customer service and this reliance on formal artifacts is likely to favor planned change, limiting the potential for improvisation.

In some service ecosystems, service is largely tacit and coordination depends mainly on shared ostensive understanding. Such ecosystems are likely to demand greater flexibility and improvisational routine performances may drive change. For example, tourism service ecosystems are typically less constrained by material artifacts; while the physical setting is fixed and some rules remain necessary, actors can experiment with new routines and inspire others to imitate. Further research is needed to clarify how the formality and materiality of routines affect institutional change processes.

By addressing these issues, future research can enhance existing knowledge about different actors' agency in emerging service ecosystems. This will provide a solid foundation for assessing how planned and practice-based change activities can be coordinated for alignment of value co-creation routines. As argued above, this alignment is important for the institutionalization of novel solutions. Table I summarizes the proposed research agenda and core assumptions.

\section{Concluding remarks}

By applying the theory of routine dynamics to conceptualize how institutional change emerges at the level of value co-creation 
Table I Future research questions

Research task and key assumptions
Power dynamics in dialectical change process
Change process can either begin from routine performance (practice-based
change) or from the design of routines (planned change). The starting point
likely influences how institutional change is achieved
Actors may have various roles and sources of power in both types of chang
activities and their agency can create unexpected turns in the institutional
change process
Power relations among actors are likely to change during an institutional
change process as new understandings, resources and roles are created
Institutional change processes in different types of service ecosystems
Differences in actors' institutional contexts likely influence the manner in
which shared ostensive understanding and alignment among different
aspects of routines can be built
Dialectics between planned and practice-based change activities in
institutional change processes are likely to be more complex when
ecosystems comprise diverse bundles of routines and actors
Dialectics between planned and practice-based change in institutional
change process are likely to differ between ecosystems where material
artifacts are important and where immaterial practices and norms are
important

Research questions

RQ1.1. How can different actors initiate change in value co-creation routines?

RQ1.2. How do individual actors influence routines in the cycles of planned and practice-based change?

RQ1.3. How do changing power relations among different actors influence the dialectics in an institutional change process?

$R Q 2.1$. How does the diversity of service ecosystems' surrounding institutions influence the dialectics of institutional change process?

$R Q 2.2$. How does the complexity of routines within a service ecosystem influence the dialectics of institutional change process?

$R Q 2.3$. How do service ecosystem formality and materiality influence the dialectics of institutional change process? practices in service ecosystems, this paper responds to calls for greater theoretical and conceptual clarity in relation to the complexities of change (Ostrom et al., 2015). In particular, the theory of routine dynamics opens up the "black box" of value cocreation practices in institutional change by addressing how the internal dynamics of value co-creation practices, conceptualized as routines, and are altered in such contexts. This approach extends the SDL view of institutional change by directing attention to the linkages between changes in institutionalized rules of resource integration (Edvardsson et al., 2014; KoskelaHuotari et al., 2016) and changes in everyday routines.

While previous studies have acknowledged that institutional change influences institutional rules, resources and practices (Koskela-Huotari et al., 2016; Vargo and Lusch, 2016), the associated interdependencies have not been rigorously conceptualized. This paper explicitly examines how the change in institutional rules is intertwined with changes in routinespecific schemas, artifacts and everyday interactions associated with value co-creation. It is argued that the institutionalization of new value co-creation routines requires alignment of internal aspects of routines with each other and with the surrounding institutions. The paper extends current accounts of the coordination of institutional change processes by modeling the interplay between planned and practice-based change as the two main types of activity in routine change. Understanding the interplay between these activities and their impact on routines illuminates how different actors contribute to and are affected by the processes of institutional change.

This approach has several implications for future research on how and why institutional change happens in service ecosystems - what enables and inhibits sustained and beneficial changes in value co-creation routines that produce viable service ecosystems (Barile et al., 2016; Vargo et al., 2017; Reynoso et al., 2018). Addressing this neglected topic by studying different kinds of service ecosystems can deepen existing understanding of institutional change, strengthening the service platform view outlined by Lusch and Nambisan (2015).

The theory of routine dynamics can also be of use to service scholars in other research areas beyond the present scope. For example, different types of service innovation can be distinguished by analyzing changes in the three aspects of routines and tracing the implications for value co-creation. This approach can also shed new light on the role of flexibility and efficiency in value co-creation processes by mapping when and how performance variations can be encouraged. Furthermore, even though routines are dynamic, they also provide stability and repetition for value co-creation actions and interactions (Feldman and Pentland, 2003), which may explain why some service ecosystems fail to change despite opportunities for innovation. In general, the research opportunities afforded by routine theories have significant untapped potential for understanding complex service contexts where the plurality of interests and cognitive and material resources challenge simple models of value creation and innovation.

\section{References}

Akaka, M.A. and Chandler, J.D. (2011), "Roles as resources: a social roles perspective of change in value networks", Marketing Theory, Vol. 11 No. 3, pp. 243-260.

Ambrosia, D.W. (1981), "New swift rules on the liability of financial institutions for interest losses caused by delay in international fund transfers", Cornell International Law Fournal, Vol. 13 No. 2, pp. 311-327.

Baker, T. and Nelson, R.E. (2005), "Creating something from nothing: resource construction through entrepreneurial 
bricolage", Administrative Science Quarterly, Vol. 50 No. 3, pp. 329-366.

Banoun, A., Dufour, L. and Andiappan, M. (2016), "Evolution of a service ecosystem: longitudinal evidence from multiple shared services centers based on the economies of worth framework", Fournal of Business Research, Vol. 69 No. 8, pp. 2990-2998.

Barile, S., Lusch, R., Reynoso, J., Saviano, M. and Spohrer, J. (2016), "Systems, networks, and ecosystems in service research", fournal of Service Management, Vol. 27 No. 4, pp. 652-674.

Bucher, S. and Langley, A. (2016), "The interplay of reflective and experimental spaces in interrupting and reorienting routine dynamics", Organization Science, Vol. 27 No. 3, pp. 594-613.

Cacciatori, E. (2012), "Resolving conflict in problem-solving: systems of artefacts in the development of new routines", Fournal of Management Studies, Vol. 49 No. 8, pp. 1559-1585.

Carlborg, P., Kindström, D. and Kowalkowski, D. (2014), "The evolution of service innovation research: a critical review and synthesis", The Service Industries fournal, Vol. 34 No. 5, pp. 373-398.

Chandler, J.D. and Chen, S. (2016), "Practice styles and service systems", fournal of Service Management, Vol. 27 No. 5, pp. 798-830.

Chowdhury, I.N., Gruber, T. and Zolkiewski, J. (2016), "Every cloud has a silver lining - exploring the dark side of value co-creation in B2B service networks", Industrial Marketing Management, Vol. 55, pp. 97-109.

Cramer, J. and Krueger, A.B. (2016), "Disruptive change in the taxi business: the case of Uber", American Economic Review, Vol. 106 No. 5, pp. 177-182.

D'Adderio, L. (2011), "Artifacts at the centre of routines: performing the material turn in routines theory", fournal of Institutional Economics, Vol. 7 No. 2, pp. 197-230.

D'Adderio, L. (2008), "The performativity of routines: theorising the influence of artefacts and distributed agencies on routines dynamics", Research Policy, Vol. 37 No. 5, pp. 769-789.

Deken, F., Carlile, P.R., Berends, H. and Lauche, K. (2016), "Generating novelty through interdependent routines: a process model of routine work", Organization Science, Vol. 27 No. 3, pp. 659-677.

Di Pietro, L., Edvardsson, B., Reynoso, J., Renzi, M.F., Toni, M. and Mugion, R.G. (2017), “a scaling up framework for innovative service ecosystems: lessons from Eataly and KidZania", Fournal of Service Management, Vol. 29 No. 1, pp. 146-175.

Dionysiou, D.D. and Tsoukas, H. (2013), "Understanding the (re)creation of routines from within: A symbolic interactions perspective", Academy of Management Review, Vol. 38 No. 2, pp. 181-205.

Dittrich, K., Guérard, S. and Seidl, D. (2016), "Talking about routines: the role of reflective talk in routine change", Organization Science, Vol. 27 No. 3, pp. 678-697.

Edvardsson, B., Kleinaltenkamp, M., Tronvoll, B., McHugh, P. and Windahl, C. (2014), "Institutional logics matter when coordinating resource integration", Marketing Theory, Vol. 14 No. 3, pp. 291-309.
Edvardsson, B. and Olsson, J. (1996), "Key concepts for new service development", The Service Industries fournal, Vol. 16 No. 2, pp. 140-164.

Edvardsson, B. and Tronvoll, B. (2013), "A new conceptualization of service innovation grounded in S-D logic and service systems", International fournal of Quality and Service Sciences, Vol. 5 No. 1, pp. 19-31.

Edvardsson, B., Tronvoll, B. and Gruber, T. (2011), "Expanding understanding of service exchange and value cocreation: a social construction approach", fournal of the Academy of Marketing Science, Vol. 39 No. 2, pp. 327-339.

Echeverri, P. and Skålén, P. (2011), "Co-creation and codestruction: a practice-theory based study of interactive value formation", Marketing Theory, Vol. 11 No. 3, pp. 351-373.

Feldman, M.S. (2000), "Organizational routines as a source of continuous change”, Organization Science, Vol. 11 No. 6, pp. 611-629.

Feldman, M.S. (2004), "Resources in emerging structures and processes of change", Organization Science, Vol. 15 No. 3, pp. 295-309.

Feldman, M.S. and Orlikowski, W.J. (2011), "Theorizing practice and practicing theory", Organization Science, Vol. 22 No. 5, pp. 1240-1253.

Feldman, M.S. and Pentland, P.T. (2003), "Reconceptualizing organizational routines as a source of flexibility and change", Administrative Science Quarterly, Vol. 48 No. 1, pp. 94-118.

Feldman, M.S., Pentland, P.T., D'Adderio, L. and Lazaric, N. (2016), "Beyond routines as things: introduction to the special issue on routine dynamics", Organization Science, Vol. 27 No. 3, pp. 505-513.

Gallouj, F. and Weinstein, O. (1997), "Innovation in services", Research Policy, Vol. 26 Nos 4/5, pp. 537-556.

Genus, A. and Jensen, C. (2019), "Beyond 'behaviour': the institutionalisation of practice and the case of energyefficient lighting in Denmark", fournal of Consumer Culture, Vol. 19 No. 3, pp. 340-358.

Giddens, A. (1984), The Constitution of Society: Outline of the Theory of Structuration, University of CA Press, Berkeley.

Hollebeek, L.D., W. Andreassen, T., Smith, D.L.G., Grönquist, D., Karahasanovic, A. and Márquez, Á. (2018), "Epilogue - service innovation actor engagement: an integrative model”, fournal of Services Marketing, Vol. 32 No. 1, pp. 95-100.

Howard-Grenville, J.A. (2005), "The persistence of flexible organizational routines: the role of agency and organizational context", Organization Science, Vol. 16 No. 6, pp. 618-636.

Kimbell, L. (2011), "Designing for service as one way of designing services", International fournal of Design, Vol. 5 No. 2, pp. 41-52.

Koskela-Huotari, K., Edvardsson, B., Jonas, J.M., Sörhammar, D. and Witell, L. (2016), "Innovation in service ecosystems breaking, making, and maintaining institutionalized rules of resource integration", Fournal of Business Research, Vol. 69 No. 8, pp. 2964-2971.

Kremser, W. and Schreyögg, G. (2016), "The dynamics of interrelated routines: introducing the cluster level", Organization Science, Vol. 27 No. 3, pp. 698-721. 
Lawrence, T.B. and Suddaby, R. (2006), "Institutions and institutional work", in Clegg, S.R., Hardy, C., Nord, W.R. and Lawrence, T.B. (Eds), Handbook of Organization Studies, 2nd ed., Sage Publication, London, pp. 215-254.

Lawrence, T.B., Suddaby, R. and Leca, B. (2011), "Institutional work: refocusing institutional studies of organization”, fournal of Management Inquiry, Vol. 20 No. 1, pp. 52-58.

Lawrence, T.B., Winn, M.I. and Jenning, P.D. (2001), "The temporal dynamics of institutionalization", Academy of Management Review, Vol. 26 No. 4, pp. 624-644.

Levina, N. and Orlikowski, W.J. (2009), "Understanding shifting power relations within and across organizations: a critical genre analysis", Academy of Management fournal, Vol. 52 No. 4, pp. 672-703.

London, T. (2012), "Constructing a base-of-the-pyramid business in a multinational corporation: CEMEX's Patrimonio Hoy looks to grow", Case Study 1-429-202, William Davidson Institute, University of Michigan, Michigan.

Lusch, R.F. and Nambisan, S. (2015), "Service innovation: a service-dominant logic perspective", MIS Quarterly, Vol. 39 No. 1, pp. 155-175.

Lusch, R.F. and Vargo, S.L. (2014), Service-Dominant Logic: Premises, Perspective, Possibilities, Cambridge University Press, New York, NY.

Mele, C., Nenonen, S., Pels, J., Storbacka, K., Nariswari, A. and Kaartemo, V. (2018), "Shaping service ecosystems: exploring the dark side of agency", fournal of Service Management, Vol. 29 No. 4, pp. 521-545.

Meynhardt, T., Chandler, J.D. and Strathoff, P. (2016), "Systemic principles of value co-creation: synergetics of value and service ecosystems", fournal of Business Research, Vol. 69 No. 8, pp. 2981-2989.

Nardelli, G. (2017), "Innovation dialectics: an extended process perspective on innovation in services", The Service Industries fournal, Vol. 37 No. 1, pp. 31-56.

Nenonen, S., Gummerus, J. and Sklyar, A. (2018), "Gamechangers: dynamic capabilities' influence on service ecosystems", fournal of Service Management, Vol. 29 No. 4, pp. 569-592.

Orlikowski, W.J. (1996), "Improvising organizational transformation over time: a situated change perspective", Information Systems Research, Vol. 7 No. 1, pp. 63-92.

Orlikowski, W.J. (2000), "Using technology and constituting structures: a practice lens for studying technology in organizations", Organization Science, Vol. 11 No. 4, pp. 404-428.

Ostrom, A.L., Parasuraman, A., Bowen, D., Patrício, L. and Voss, C.A. (2015), "Service research priorities in a rapidly changing context”, fournal of Service Research, Vol. 18 No. 2, pp. 127-159.

Pentland, B.T. and Feldman, M.S. (2008), "Designing routines: on the folly of designing artifacts, while hoping for patterns of action", Information and Organization, Vol. 18 No. 4, pp. 235-250.

Pentland, B.T., Hærem, T. and Hillison, D. (2011), "The (n)ever-changing world: stability and change in organizational routines", Organization Science, Vol. 22 No. 6, pp. 1369-1383.
Pentland, B.T., Feldman, M.S., Becker, M.C. and Liu, P. (2012), "Dynamics of organizational routines: a generative model", Fournal of Management Studies, Vol. 49 No. 8, pp. 1484-1508.

Pietarinen, J., Pyhältö, K. and Soini, T. (2017), "Shared sensemaking in curriculum reform: orchestrating the local curriculum work", Scandinavian fournal of Educational Research, Vol. 63 No. 4, pp. 1-15.

Reynoso, J., Barile, S., Saviano, M. and Sphorer, J. (2018), "Systems, networks and service ecosystems: connecting the dots", in Lusch, R. and Vargo, S. (Eds), The SAGE Handbook of Service Dominant Logic, SAGE, Thousand Oaks, CA, pp. 241-260.

Roy, B. and Harigan, J. (2008), "Empowering the rural poor to develop themselves: the barefoot approach", Innovations, Vol. 3 No. 2, pp. 67-93.

Sandholtz, K.W. (2012), "Making standards stick: a theory of coupled vs. decoupled compliance", Organization Studies, Vol. 33 Nos 5/6, pp. 655-679.

Schau, H.J., Muñiz, A.M. and Arnould, E.J. (2009), "How brand community practices create value", fournal of Marketing, Vol. 73 No. 5, pp. 30-51.

Scott, W.R. (2001), Institutions and Organizations, 2nd ed., Sage Publications, Thousand Oaks, CA.

Segel, A.I., Chu, M. and Herrero, G.A. (2006), "Patrimonio Hoy", Case Study 9-805-064, Harvard Business School, Boston.

Shove, E., Pantzar, M. and Watson, M. (2012), The Dynamics of Social Practice: Everyday Life and How It Changes, Sage, London.

Siltaloppi, J., Koskela-Huotari, K. and Vargo, S.L. (2016), "Institutional complexity as a driver for innovation in service ecosystems", Service Science, Vol. 8 No. 3, pp. 333-343.

Skålén, P., Kotaiba, A.A. and Edvardsson, B. (2015a), "Cocreating the Arab spring: understanding transformation of service systems in contention", Fournal of Service Research, Vol. 18 No. 3, pp. 250-264.

Skålén, P., Gummerus, J., von Koskull, C. and Magnusson, P.R. (2015b), "Exploring value propositions and service innovation: a servicedominant logic study", Fournal of the Academy of Marketing Science, Vol. 43 No. 2, pp. 1-22.

Taillard, M., Peters, L.D., Pels, J. and Mele, C. (2016), "The role of shared intentions in the emergence of service ecosystems", Fournal of Business Research, Vol. 69 No. 8, pp. 2972-2980.

Thomke, S. (2012), “Mumbai's models of service excellence", Harvard Business Review, Vol. 90 No. 11, pp. 121-126.

Toivonen, M. and Tuominen, T. (2009), "Emergence of innovations in services", The Service Industries fournal, Vol. 29 No. 7, pp. 887-902.

Tsoukas, H. and Chia, R. (2002), "On organizational becoming: rethinking organizational change", Organization Science, Vol. 13 No. 5, pp. 567-582.

Van de Ven, A. and Poole, M.S. (1995), "Explaining development and change in organizations", Academy of Management Review, Vol. 20 No. 3, pp. 510-540. 
Vargo, S.L., Koskela-Huotari, K., Baron, S., Edvardsson, B., Reynoso, J. and Colurcio, M. (2017), "A systems perspective on markets-toward a research agenda", fournal of Business Research, Vol. 79 No. 1, pp. 260-268.

Vargo, S.L. and Lusch, R. (2016), "Institutions and axioms: an extension and update of service-dominant logic", fournal of the Academy of Marketing Science, Vol. 44 No. 1, pp. 5-23.

Vargo, S.L., Wieland, H. and Akaka, M.A. (2015), "Innovation through institutionalization: a service ecosystems perspective", Industrial Marketing Management, Vol. 44, pp. 63-72.

Wetter-Edman, K., Daniela, S., Edvardsson, B., Holmlid, S., Grönroos, C. and Mattelmäki, T. (2014), "Design for value co-creation: exploring synergies between design for service and service logic", Service Science, Vol. 6 No. 2, pp. 106-121.

Windrum, P., Schartinger, D., Rubalcaba, R., Gallouj, F. and Toivonen, M. (2016), "The co-creation of multi-agent social innovations: a bridge between service and social innovation research", European fournal of Innovation Management, Vol. 19 No. 2, pp. 150-166.

Witell, L., Snyder, H., Gustafsson, A., Fombelle, P. and Kristensson, P. (2016), "Defining service innovation: a review and synthesis", fournal of Business Research, Vol. 69 No. 8, pp. 2863-2872.

Yu, E. and Sangiorgi, D. (2018), "Service design as an approach to implement the value cocreation perspective in new service development", fournal of Service Research, Vol. 21 No. 1, pp. 40-58.

\section{Further reading}

Sembada, A. (2018), "The two sides of empowering consumers to co-design innovations", Fournal of Services Marketing, Vol. 32 No. 1, pp. 8-18.

\section{About the authors}

Tiina Tuominen is a Postdoctoral Researcher at Tampere University, Faculty of Management and Business. Previously, she has acted as a as a Postdoctoral Researcher and Research Manager at Aalto University School of Science and as a
Postdoctoral Researcher at Hanken School of Economics, Department of Marketing. Her research addresses individual and collective aspects of innovation and change in service organizations, with a focus on employees' transformative agency in public service organizations. Tiina Tuominen is the corresponding author and can be contacted at: tiina.tuominen@, tuni.fi

Bo Edvardsson is Professor and founder of Service Research Center-CTF, Karlstad University, Sweden. $\mathrm{He}$ is also Professor II at Inland Norway University of Applied Sciences. In 2008, he received the RESER Award. In 2008, he received the RESER Award "Commendation for lifetime achievement to scholarship" by The European Association for Service Research and in 2004 The AMA Career Contributions to the Services Discipline Award. In 2013 Bo was appointed Distinguished Faculty Fellow of the Center for Excellence in Service, University of Maryland and Honorary Distinguished Professor of Service Management, EGADE Business School, Monterrey Tech, Mexico. His research includes new service development and innovation, customer experience, complaint management, service eco-systems and transition from product to service in manufacturing.

Javier Reynoso is a member of the faculty of EGADE Business School at Tecnologico de Monterrey (ITESM) in Monterrey, Mexico, where he designed and coordinated both the bachelors and graduate certificates on Service Management. His main interest is to promote and develop research and academic activities on Service Management in Mexico and Latin America. He is co-author of the first textbook on Service Management written in Spanish, used in 20 countries. Listed in the Top 15 MBA Professors in Latin America, by Revista America Economia in 2012, he has received on three occasions, 1999, 2005 and 2013, the ITESM's Teaching and Research Faculty Award for his contributions in the service sector. He received the prestigious Christian Grönroos Service Research Award 2013 in recognition of his career achievements and significant originality in service research, and in 2016 he was appointed as International Fellow of CTF Service Research Center at Karlstad University in Sweden. He is a member of the Mexican Academy of Sciences since 2017. 